 \\ ENVIRONMENTAL RESEARCH BRIEF
}

\section{Pollution Prevention Assessment for a Manufacturer of Rebuilt Industrial Crankshafts}

\author{
Harry W. Edwards*, Michael F. Kostrzewa*, \\ and Gwen P. Looby ${ }^{\star \star}$
}

\section{RECEIVED OCT 241935}

\begin{abstract}
The U.S. Environmental Protection Agency (EPA) has funded a pilot project to assist small and medium-size manufacturers who want to minimize their generation of waste but who lack the expertise to do so. In an effort to assist these manufacturers Waste Minimization Assessment Centers (WMACs) were established at selected universities and procedures were adapted from the EPA Waste Minimization Opportunity Assessment Manual (EPA/625/7-88/003, July 1988). That document has been superseded by the Facility Pollution Prevention Guide. (EPA/600/R-92/088, May 1992). The WMAC team at Colorado State University performed an assessment at a plant that refurbishes large industrial crankshafts. Worn crankshafts received by the plant are cleaned and stripped of chromium. The crankshafts are inspected for defects, repaired as required, annealed, and straightened. Bearing surfaces are rough ground, crankshaft journal surfaces are shot-peened, and the crankshafts are cleaned. Then the crankshaft surfaces and selected bearing surfaces are electrochemically plated with chromium. Next, the crankshafts are baked, shot-peened again, and fine ground to final specifications. The team's report, detailing findings and recommendations, indicated that the waste stream generated in the greatest quantity is spent cutting fluid from the grinding of crankshafts and that significant cost savings could be achieved by implementing a formal cutting fluid management program.
\end{abstract}

This Research Brief was developed by the principal investigators and EPA's National Risk Management Research Laboratory, Cincinnati, $\mathrm{OH}$, to announce key findings of an ongoing research project that is fully documented in a separate report of the same title available from University City Science Center.

\footnotetext{
- Colorado State University, Department of Mechanical Engineering

" University City Science Center, Philadelphia, PA
}

\section{Introduction}

207

The amount of waste generated by industrial plants has become an increasingly costly problem for manufacturers and an additional stress on the environment. One solution to the problem of waste generation is to reduce or eliminate the waste at its source.

University City Science Center (Philadelphia, PA) has begun a pilot project to assist small and medium-size manufacturers who want to minimize their generation of waste but who lack the in-house expertise to do so. Under agreement with EPA's National Risk Management Research Laboratory, the Science Center has established three WMACs. This assessment was done by engineering faculty and students at Colorado State University's (Fort Collins) WMAC. The assessment teams have considerable direct experience with process operations in manufacturing plants and also have the knowledge and skills needed to minimize waste generation.

The pollution prevention opportunity assessments are done for small and medium-size manufacturers at no out-of-pocket cost to the client. To qualify for the assessment, each client must fall within Standard Industrial Classification Code 20-39, have gross annual sales not exceeding $\$ 75$ million, employ no more than 500 persons, and lack in-house expertise in pollution prevention.

The potential benefits of the pilot project include minimization of the amount of waste generated by manufacturers, and reduction of waste treatment and disposal costs for participating plants. In addition, the project provides valuable experience for graduate and undergraduate students who participate in the program, and a cleaner environment without more regulations and higher costs for manufacturers.

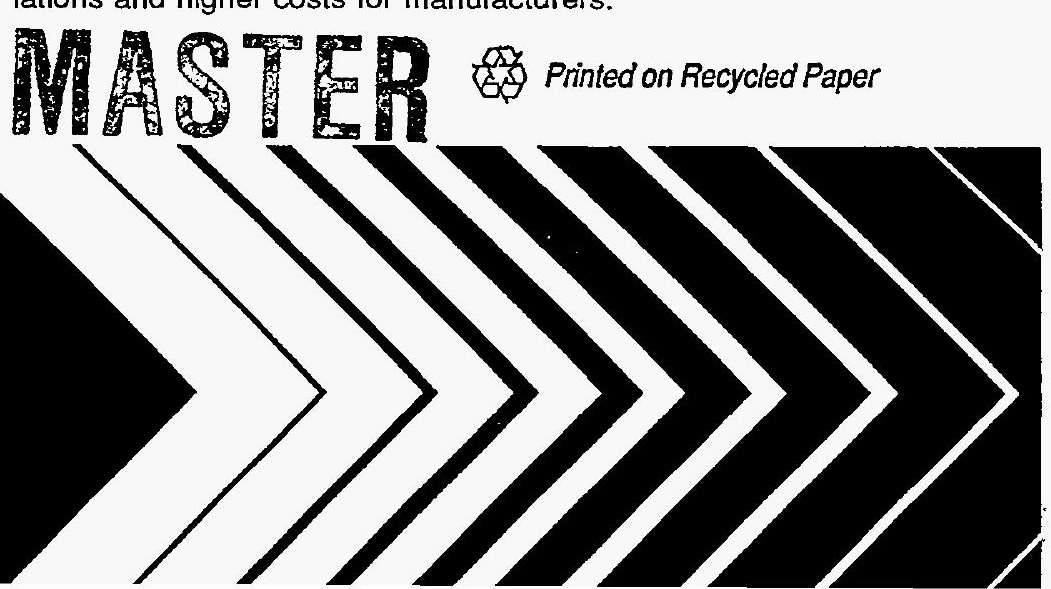




\section{Methodology of Assessments}

The pollution prevention opportunity assessments require several site visits to each client served. In general, the WMACs follow the procedures outlined in the EPA Waste Minimization Opportunity Assessment Manual (EPA/625/7-88/003, July 1988). The WMAC staff locate the sources of waste in the plant and identify the current disposal or treatment methods and their associated costs. They then identify and analyze a variety of ways to reduce or eliminate the waste. Specific measures to achieve that goal are recommended and the essential supporting technological and economic information is developed. Finally, a confidential report that details the WMAC's findings and recommendations (including cost savings, implementation costs, and payback times) is prepared for each client.

\section{Plant Background}

This plant rebuilds large industrial crankshafts that are distributed regionally. Over 4,000 jobs are completed each year by the plant during $2,210 \mathrm{hr} / \mathrm{yr}$ of operation.

\section{Manufacturing Process}

Worn crankshafts received by the plant are cleaned and degreased in a heated caustic solution. Chromium plating is then electrolytically stripped from the crankshafts in a caustic solution. The chromium may also be removed mechanically using large grinders.

Next, the crankshafts are inspected for cracks and flaws using two different methods. One method entails applying a penetrating fluorescent dye solution and a visual inspection using a UV-light. The second method involves the use of a solvent containing fine, magnetic particles and application of a magnetic field which is distorted by any defects present.

Defects are repaired and worn metal is built up using arc welding. Stresses are relieved in an annealing oven and a hydraulic press is used to straighten the crankshafts as needed. The bearing surfaces are then rough ground to desired factory specifications.

Following grinding, the crankshafts are prepared for chromium plating. The crankshaft journal surfaces are shot-peened to relieve surface stresses, and the crankshafts are cleaned with air-blown abrasive particles. Keyways are plugged with lead to prevent plating of their surfaces and masking is applied as needed to prevent plating of other surfaces. The crankshaft surfaces and selected bearing surfaces are electrochemically plated with chromium using heated chromic acid plating baths.

After plating, the crankshafts are baked to remove hydrogen absorbed during plating, shot-peened again, and fine ground to final specifications. A final magnetic particle inspection follows grinding. The shafts are then dynamically balanced, polished, and packaged and shipped to customers or added to inventory.

An abbreviated process flow diagram for the rebuilding of crankshafts is shown in Figure 1.

\section{Existing Waste Management Practices}

This plant already has implemented the following techniques to manage and minimize its wastes.

- All rinsing of crankshafts is done over process solution tanks to reduce effluent to the sewer.
- Electrodialysis is used to maintain the chromium plating baths, thereby extending bath life and reducing the need for replacing the plating solutions.

- Lead anodes are melted and repoured to reduce the generation of waste lead.

\section{Pollution Prevention Opportunities}

The type of waste currently generated by the plant, the source of the waste, the waste management method, the quantity of the waste, and the waste management cost for each waste stream identified are given in Table 1.

Table 2 shows the opportunities for pollution prevention that the WMAC team recommended for the plant. The opportunity, the type of waste, the possible waste reduction and associated savings, and the implementation cost along with the simple payback time are given in the table. The quantities of waste currently generated by the plant and possible waste reduction depend on the production level of the plant. All values should be considered in that context.

It should be noted that the economic savings of the opportunities, in most cases, result from the reduction in raw material and from reduced present and future costs associated with waste treatment and disposal. Other savings not quantifiable by this study include a wide variety of possible future costs related to changing emissions standards, liability, and employee health. It also should be noted that the savings given for each opportunity reflect that pollution prevention opportunity only and do not reflect duplication of savings that may result when the opportunities are implemented in a package.

\section{Additional Recommendations}

In addition to the opportunities recommended and analyzed by the WMAC team, several other measures were considered. These measures were not analyzed completely because of insufficient data, implementation difficulty, or a projected lengthy payback. Since these approaches to pollution prevention may, however, increase in attractiveness with changing conditions in the plant, they were brought to the plant's attention for future consideration.

- Replace the rented parts washers that use petroleum naphtha with alternative cleaning systems using a less hazardous solvent.

- Develop a formal management plan for the maintenance of the chromium plating solutions to increase bath life and reduce waste generation. Specialemphasis should be placed on the maintenance and performance of the electrodialysis equipment. Several measures are in place to maintain the solutions, but procedures should be formalized.

- Investigate possible alternatives to the landfilling of chromium-contaminated soil and evaporator sludge stored onsite pending identification of a suitable disposal method. Further analysis requires sampling and quantitative analysis of the chromium bearing wastes to determine the suitability of recycling. Such procedures are beyond the scope of the WMAC program.

This research brief summarizes a part of the work done under Cooperative Agreement No. CR-819557 by the University City Science Center under the sponsorship of the U. S. Environmental Protection Agency. The EPA Project Officer was Emma Lou George. 


\section{DISCLAIMER}

This report was prepared as an account of work sponsored by an agency of the United States Government. Neither the United States Government nor any agency thereof, nor any of their employees, makes any warranty, express or implied, or assumes any legal liability or responsibility for the accuracy, completeness, or usefulness of any information, apparatus, product, or process disclosed, or represents that its use would not infringe privately owned rights. Reference herein to any specific commercial product, process, or service by trade name, trademark, manufacturer, or otherwise does not necessarily constitute or imply its endorsement, recommendation, or favoring by the United States Government or any agency thereof. The views and opinions of authors expressed herein do not necessarily state or reflect those of the United States Government or any agency thereof. 


\section{DISCLAIMER}

Portions of this document may be illegible in electronic image products. Images are produced from the best available original document. 
Worn Crankshatts
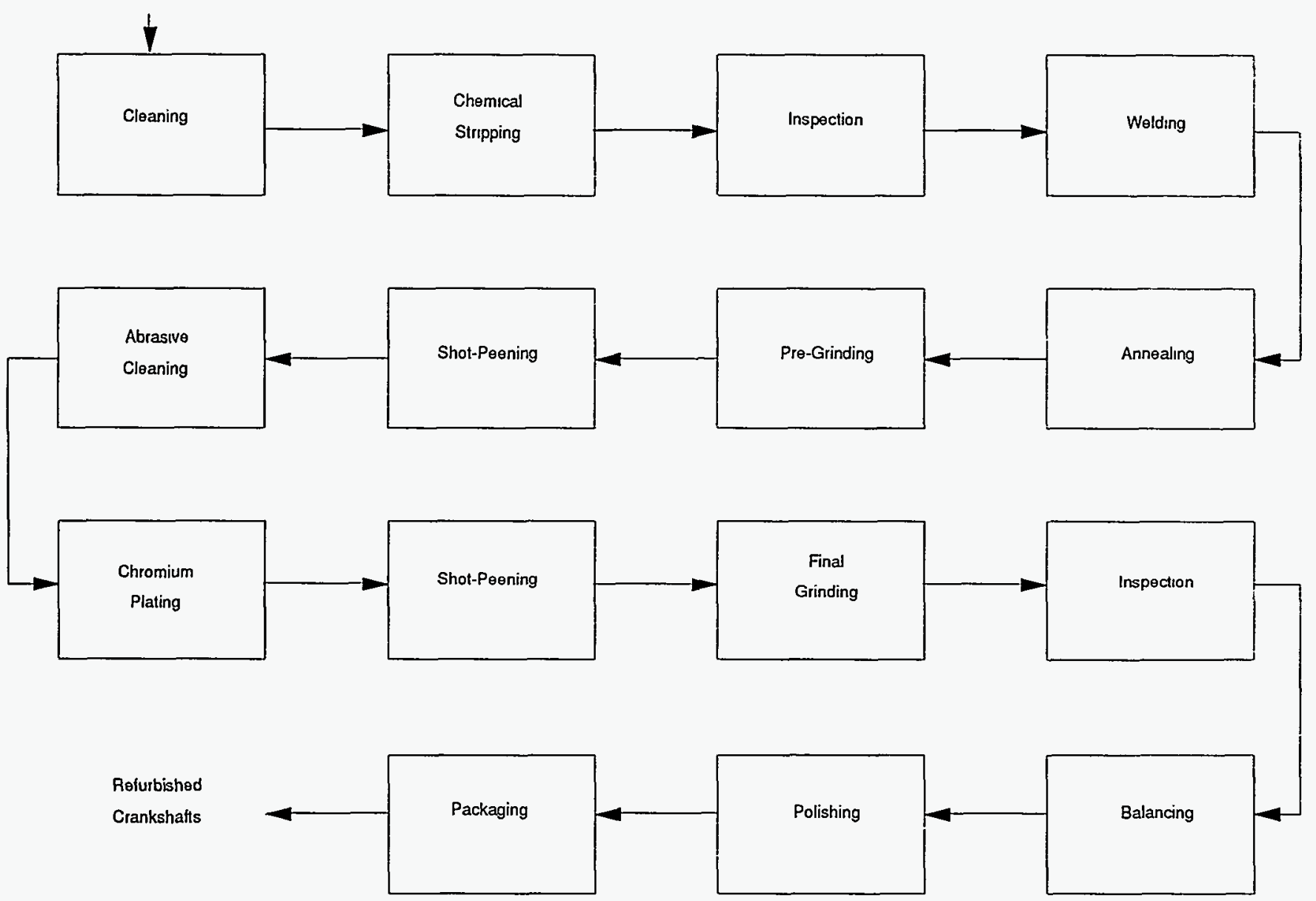

Figure 1. Process flow diagram for industrial crankshaft refurbishing. 
Table 1. Summary of Current Waste Generation

\begin{tabular}{|c|c|c|c|c|}
\hline Waste Stream Generated & Source of Waste & Waste Management Method & $\begin{array}{l}\text { Annual Quantity } \\
\text { Generated (Ib/yr) }\end{array}$ & $\begin{array}{l}\text { Annual Waste } \\
\text { Management Cost }\end{array}$ \\
\hline Waste caustic cleaning solution & Initial cleaning of crankshafts & $\begin{array}{l}\text { Stored onsite pending determination of an } \\
\text { appropriate waste management method } 7\end{array}$ & 41,800 & $\$ 2,130^{2}$ \\
\hline Waste stripping solution & Chromium stripping of crankshafts & $\begin{array}{l}\text { Stored onsite pending determination of a } \\
\text { appropriate waste management method }\end{array}$ & 30,000 & 0 \\
\hline Evaporated penetrant/dye & Inspection of crankshafts & Evaporated to plant air & 1,110 & $280^{2}$ \\
\hline Spent parts cleaning solvent & Parts washer & $\begin{array}{l}\text { Removed by supplier; distilled offsite for } \\
\text { reuse or incinerated }\end{array}$ & 1,810 & 1,250 \\
\hline Spent cutting fluid & Grinding of crankshafts & $\begin{array}{l}\text { Filtered from grinding sludge; drained } \\
\text { through sand trap; sewered as industrial } \\
\text { wastewater }\end{array}$ & 178,700 & $6,560^{2}$ \\
\hline Grinding sludge & Grinding of crankshafts & $\begin{array}{l}\text { Shipped offsite for stabilization and burial } \\
\text { at a hazardous waste disposal facility }\end{array}$ & 25,400 & 8,300 \\
\hline Waste hydraulic oil & Routine maintenance of grinders & $\begin{array}{l}\text { Removed by oil recycler; blended to produce } \\
\text { industrial boiler fuel }\end{array}$ & 2,350 & 60 \\
\hline Evaporator sludge & $\begin{array}{l}\text { Previous waste management } \\
\text { method for caustic wastes }\end{array}$ & $\begin{array}{l}\text { Stored onsite pending determination of an } \\
\text { appropriate waste management method }\end{array}$ & 13,600 & 0 \\
\hline Waste stripping solution & Rework of plated crankshafts & $\begin{array}{l}\text { Stored onsite pending determination of an } \\
\text { appropriate waste management method }\end{array}$ & 10,000 & 0 \\
\hline Lead slag & Preparation of anodes for plating & Accumulated onsite & 9,160 & 0 \\
\hline Waste caustic cleaning solution & Cleaning of anodes & $\begin{array}{l}\text { Stored onsite pending determination of an } \\
\text { appropriate waste management method }{ }^{1}\end{array}$ & 1,500 & $2,500^{2}$ \\
\hline
\end{tabular}

1 Prior to the assessment, the caustic wastes were combined and placed in an evaporator. The evaporator was used to reduce the volume and weight of waste prior to disposal. At the time of the assessment these wastes were being stored onsite. Filtration and the use of a sludge dryer were being considered as alternative waste management methods.

2 Includes applicable lost raw material value. 
Table 2. Summary of Recommended Pollution Prevention Opportunities

\begin{tabular}{|c|c|c|c|c|c|c|}
\hline \multirow[b]{2}{*}{ Pollution Prevention Opportunity } & \multirow[b]{2}{*}{ Waste Stream Reduced } & \multicolumn{2}{|c|}{ Annual Waste Reduction } & \multirow{2}{*}{$\begin{array}{l}\text { Net Annual } \\
\text { Savings }\end{array}$} & \multirow{2}{*}{$\begin{array}{l}\text { Implementation } \\
\text { Cost }\end{array}$} & \multirow{2}{*}{$\begin{array}{c}\text { Simple } \\
\text { Payback }(y r)\end{array}$} \\
\hline & & Quantity (lb/yr) & Per Cent & & & \\
\hline $\begin{array}{l}\text { Install a high pressure washer and filtration } \\
\text { system for the caustic solution used to } \\
\text { provide the initial crankshaft cleaning. } \\
\text { It is proposed that a small spray washer } \\
\text { be used to clean the crankshafts over the } \\
\text { caustic tank and a filtration system be } \\
\text { used to remove particulate matter from the } \\
\text { solution, thereby extending the life of the } \\
\text { solution. }\end{array}$ & $\begin{array}{l}\text { Waste caustic cleaning } \\
\text { solution }\end{array}$ & 26,500 & 63 & $\$ 4,450$ & $\$ 910$ & 0.2 \\
\hline $\begin{array}{l}\text { Implement a formal culting fluid manage- } \\
\text { ment program for the grinders that use } \\
\text { aqueous cutting fluids. The program } \\
\text { should involve daily and regular main- } \\
\text { tenance, periodic cleaning, data gath- } \\
\text { ering and tracking, and filtering of } \\
\text { particulate matter. A reduced volume } \\
\text { of waste grinding fluid will be generated } \\
\text { as a result of the program. }\end{array}$ & Spent cutting fluid & 119,000 & 67 & 3,680 & 4,360 & 1.2 \\
\hline $\begin{array}{l}\text { Filter the solvent used for magnetic in- } \\
\text { spection of the crankshafts in order to } \\
\text { increase its life. The solvent would be } \\
\text { pumped from the existing tank, filtered, } \\
\text { and returned. }\end{array}$ & Evaporated penetrant/dye & 550 & 50 & 270 & 110 & 0.4 \\
\hline
\end{tabular}

